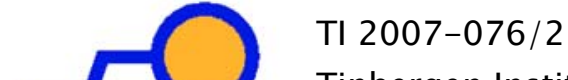

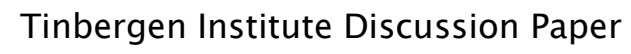 \\ $\square$ Will Corporate Tax Consolidation improve Efficiency in the EU?
}

Albert van der Horst'
Leon Bettendorf
Hugo Rojas-Romagosa'

${ }^{\prime}$ CPB Netherlands Bureau for Economic Policy Analysis, The Hague;

2 Erasmus University Rotterdam, and Tinbergen Institute. 


\section{Tinbergen Institute}

The Tinbergen Institute is the institute for economic research of the Erasmus Universiteit Rotterdam, Universiteit van Amsterdam, and Vrije Universiteit Amsterdam.

Tinbergen Institute Amsterdam

Roetersstraat 31

1018 WB Amsterdam

The Netherlands

Tel.: $\quad+31(0) 205513500$

Fax: $\quad+31(0) 205513555$

Tinbergen Institute Rotterdam

Burg. Oudlaan 50

3062 PA Rotterdam

The Netherlands

Tel.: $\quad+31(0) 104088900$

Fax: $\quad+31(0) 104089031$

Most TI discussion papers can be downloaded at http:/ /www.tinbergen.nl. 


\title{
Will corporate tax consolidation improve efficiency in the EU?
}

\author{
Albert van der Horst*, Leon Bettendorf ${ }^{\dagger}$ and Hugo Rojas-Romagosa ${ }^{\ddagger}$
}

September 2007

\begin{abstract}
The European Commission favours the introduction of a consolidated corporate tax base to overcome the distortions arising from the existing system of separate accounting. The blueprints for consolidation are simulated with the applied general equilibrium model CORTAX. We show that the benefits of a common consolidated tax base are limited due to two weaknesses. Formula apportionment, which is needed to allocate the consolidated taxable profits across jurisdictions, creates for MNEs new tax planning possibilities to exploit tax rate differentials in the European Union. In addition, it triggers tax competition as the incentives for member states to attract foreign investment by reducing their tax rates are enforced. The second weakness arises from the unlevel playing field, which is introduced if only part of the firms chooses to participate in the consolidation. The gains from consolidation can be fully grasped if it is obliged for all firms and accompanied by harmonisation of the tax rate. Key words: corporate tax, consolidation, formula apportionment, European Union, applied general equilibrium model

JEL codes: H87,H21,H25,F21
\end{abstract}

${ }^{*}$ CPB Netherlands Bureau for Economic Policy Analysis, E-mail: A.van.der.Horst@cpb.nl. Corresponding author: CPB, P.O. Box 80510, 2508GM, The Hague, The Netherlands. Tel: +31 70 3383402. Fax: +31 703383350 .

${ }^{\dagger}$ Erasmus University Rotterdam, Tinbergen Institute and CPB. E-mail: bettendorf@few.eur.nl.

${ }^{\ddagger}$ CPB Netherlands Bureau for Economic Policy Analysis, E-mail: H.A.Rojas@cpb.nl. Comments by Ruud de Mooij and Gaetan Nicodeme are gratefully acknowledged. 


\section{Introduction}

Multinational enterprises operating in the internal market are hampered by tax obstacles such as high compliance costs and the lack of cross-border loss compensation. These obstacles are inherent in the current system of separate accounting (SA), where the corporate income of foreign subsidiaries of multinational enterprises (MNEs) is treated separately for tax purposes. To tackle these tax distortions the European Commission proposes to create a single tax base for European MNEs. Taxation of a MNE will be based on a consolidated tax base for the whole of its EU operations, rather than on profits in each individual member state (European Commission, 2002, 2005, 2006). To the best of our knowledge, this paper provides the first applied general equilibrium assessment of the different consolidation proposals. We show how the distribution of the welfare effects over the countries depends on the specific particularities of the proposals. These simulation outcomes complement the results derived from simplified theoretical models (Devereux, 2004; Gérard, 2002; Nicodme, 2006).

The key elements of the EC-proposals are summarised in Table 1. We classify them along the lines of three crucial choices which have to be made. First, is consolidation compulsory, or are firms allowed to stick to the current system of country specific tax bases? Second, does consolidation involve the introduction of a 'new' European corporate tax base? Third, is consolidation accompanied with some kind of tax rate harmonisation? In addition, formula apportionment (FA) will be needed to distribute the tax base between the member states. Which measures of economic activity will be used to determine the fraction of the consolidated base generated in each jurisdiction is an important fourth choice, on which the Commission is silent though.

Table 1: Classification of EC-proposals

\begin{tabular}{llll}
\hline & mode & base & rate \\
\hline Home state taxation (HST) & optional & national & national \\
Common consolidated base taxation $(\mathrm{CCBT})$ & optional & EU & national \\
Compulsory harmonised corporate tax base (CHCTB) & compulsory & EU & national \\
European Union company income tax (EUCIT) & compulsory & EU & EU \\
\hline
\end{tabular}

There is no consensus among tax experts about the consequences of the EC-proposals. The expected benefits include the elimination of profit shifting trough transfer pricing, the reduction in compliance costs involved in filing tax returns for each jurisdiction and the improved ability for cross-border loss relief (Weiner, 2002; Devereux, 2004; Nicodme, 2006). Most authors, however, coincide that the main challenge is that consolidation, 
in particular the introduction of formula apportionment, introduces new means of tax planning (Hellerstein and McLure, 2004; Gérard, 2006; Martens-Weiner, 2006; Nielsen et al., 2006). In the new system firms may be able to change the size and location of their activities to take advantage of the formula factors. ${ }^{1}$ Governments may respond by choosing the optimal apportionment formula or, if this will not be allowed, by underbidding each others tax rates. ${ }^{2}$ Consolidation may thus intensify tax competition and curb corporate tax revenues (Cnossen, 2003).

An important shortcoming of the HST and CCBT proposals is that it is not compulsory for all firms and/or member states to participate. Under these circumstances tax revenues likely decline, since firms only switch to the new EU-system if it implies a lower tax burden. ${ }^{3}$ In addition, it may open the possibility for MNEs to apply tax planning strategies between participating and non-participating countries (Martens-Weiner, 2006). For tax authorities it also implies the administration of two corporate tax systems, while it increases the difficulties involved with the technical issue of defining a MNE. ${ }^{5}$ In turn, this may create distortions between large and small firms within Member States (Sørensen, 2004).

Empirical studies for the US bear out that formula apportionment affects MNEs decisions. Klassen and Shackelford (1998) report a significant negative relation between the sales excise rate (i.e. CIT statutory rate times the sales factor weight) and the location of MNE activities. Gupta and Hofmann (2003) find an elasticity in the range of -0.18 to -0.35 , for new capital expenditures with respect to the capital excise rate. Finally, Goolsbee and Maydew (2000) present strong empirical evidence supporting that the apportionment formula affects MNEs decisions. In particular, they find a significant reaction

\footnotetext{
${ }^{1}$ See McLure (1980) and Gordon and Wilson (1986) for early theoretical treatments of the main tax distortions created by formula apportionment.

${ }^{2}$ The ability of each tax jurisdiction to change and strategically determine its factor weights, is in general found to have negative welfare implications, see for example Omer and Shelley (2004) and Goolsbee and Maydew (2000).

${ }^{3}$ Devereux and Loretz (2007) calculate that overall tax revenues in the EU will drop by $1 \%$ if the system is voluntary, while revenues will increase by $8 \%$ if it is compulsory. These results are based on a large firm-level database, under the condition that MNEs choose the tax system that minimizes their tax payments, but otherwise do not react to the reform.

${ }^{4}$ The integration of the consolidated FA system with the rest of the world is treated in Riedel and Runkel (2007). They find that when tax rates are fixed in the short run, profit shifting to non-participating countries diminishes with FA. When they allow for tax rate competition in a long-run approach, the results are similar but less clear-cut.

${ }^{5}$ Mintz and Smart (2004) and Hellerstein and McLure (2004) point that MNEs will have incentives to break up into different subsidiaries to reduce their tax payments.
} 
of state employment to changes in the payroll weights. A reduction in the payroll weight from $1 / 3$ to $1 / 4$ increases employment by around $1.1 \%$.

The existing empirical and theoretical literature points at the economic implications of consolidation with formula apportionment, but is unable to investigate these effects simultaneously. The computable general equilibrium (CGE) approach followed in this paper shows the total effect of consolidation for the European economies. Moreover, it allows for asymmetric countries, whereas most of the theoretical literature is restricted to symmetric settings.

Only a few examples of relevant general equilibrium simulations are available in the literature. Edmiston (2002) applies a CGE model to strategic formula apportionment policies in the US. Sørensen (2004) simulates with a CGE model for the OECD the welfare gains from a complete CIT rate and base harmonization in the EU. He does not consider the consolidation of the tax base with formula apportionment.

We have developed the CORTAX model to investigate corporate tax reforms in the European Union. The model captures the main features of corporate income taxation in $17 \mathrm{EU}$ member states and the United States. It includes the investment and labourdemand decisions of both MNEs and domestic firms. Moreover, the model allows for a welfare analysis by considering the optimal response of households to changes in taxes and factor rewards. This welfare analysis sheds light on the efficiency of the corporate income tax system in the European Union and on the distribution of the gains and losses of consolidation. These welfare effects are decomposed into three elements: the introduction of a common base; the use of formula apportionment; and the reduction in compliance costs.

Section 2 introduces the CORTAX-model and describes in particular how we implement consolidation, formula apportionment and compliance costs. The subsequent sections discuss our four main findings. First, as the European Commission (2006) favours the introduction of a common consolidated corporate tax base (similar to the CCBT), Section 3 starts with analysing this system. Our simulations reveal that the European Union hardly benefits on average from such common consolidated base taxation. Clearly, there are efficiency gains from a reduction in compliance costs and the elimination of transfer pricing. These benefits are, however, offset by the new tax distortions introduced by formula apportionment and by the uneven treatment of firms.

Though neutral on average, consolidation does involve distributional effects over the countries. Welfare improves in member states with large shares of multinational enterprises, below-average tax rates and/or current broader-than-average tax bases. A low tax rate matters, because it makes member states relatively attractive for multinationals. An 
initial broad tax base matters, because the common base (defined at the EU-average) is less distortive. And the openness of countries matter, because these countries are most sensitive to corporate tax reforms.

Second, the design of the apportionment formula matters for the distribution of the welfare gains and losses over the countries, whereas the EU-average is hardly affected. The way in which the tax base is distributed affects production reallocation by MNEs. In particular when a large weight is attached to employment in the formula, tax planning strategies exploit tax-rate differentials as well as factor-price differentials. Section 4 investigates the consequences of the choice of the apportionment formula, within the CCBT-framework.

The third finding is that tax competition is intensified with common consolidated base taxation. In particular, relatively open economies have stronger incentives to reduce their tax rate with a consolidated tax base than with separate accounting. Section 5 deals with competition in tax rates.

We finally find that consolidation could result in welfare gains for all member states when the CCBT is adjusted in two ways. First, compulsory consolidation will limit heterogeneity in the corporate tax system as all firms are treated equally. Reducing tax-base related incentives for multinational enterprises improves the efficiency in the European economies. Secondly, the heterogeneity in corporate tax systems may be eliminated if tax rates are harmonised too, which greatly limits the tax planning response by firms to formula apportionment. Section 6 investigates the key alternatives in the EC-proposals, namely the choice for consolidation with home state taxation, the voluntariness of consolidation and the virtues of harmonisation of the tax rates.

Section 7 summarises our main findings. 


\section{The Model}

The proposed reforms of corporate income taxation in the EU are simulated with the general equilibrium model CORTAX. The development of this model is heavily inspired by the OECDTAX-model of Sørensen (2001). The key extension in the current study is the inclusion of consolidation and formula apportionment.

We first describe the main features of the model. Thereafter, the modelling is briefly discussed per sector. Attention is in particular given to the specification of corporate taxation in subsection $2.4 .^{6}$

\subsection{Main features of the model}

- The model includes 17 EU-countries and the US. The EU-countries are the 15 old member states (with BEL and LUX joined) and the three largest new member states (CZE, HUN and POL).

- All markets are characterised by perfect competition. Location specific rents are introduced so that profits are not zero.

- All countries produce one homogenous good at the exogenous world price (the net supply by the rest of the world (ROW) is assumed perfectly elastic at the given price).

- Two type of assets are traded on the world capital market: bonds and equities. Bonds issued in different countries are considered perfect substitutes, yielding the same given world interest rate. The same holds for equities. An individual country cannot affect world interest rates (the net supply of each asset by ROW is assumed perfectly elastic at the given interest rate).

- We focus on the steady state version of the model. Calculation of the full transition path is beyond the scope of the current study.

\subsection{Households}

Following the standard overlapping generations model of Diamond, households are assumed to live for two periods. Household decisions on consumption and labour supply are derived from the maximisation of lifetime utility, which allows for a proper welfare analysis. An individual only works when young. Young households receive labour income (after

\footnotetext{
${ }^{6}$ A detailed technical description of the model and its calibration can be found in Bettendorf and van der Horst $(2006,2007)$.
} 
taxes) and lump sum transfers. The difference between total income and consumption expenditures (including taxes) gives total savings. These savings are invested in bonds and stocks. Since both asset types are considered imperfect substitutes, an investor prefers to diversify his portfolio over both assets. Since older households do no work, consumption in the second period has to be financed by capital income (net of taxes), together with lump sum transfers.

Calibration is in general based on data from 2002. Consumption expenditures are taken from the National Accounts, while labour supply is calculated from data on employment in persons and hours. Values for the main parameters of the household sector are given in Table 2.

Table 2: Key parameters and (semi-)elasticities for households ${ }^{a}$

\begin{tabular}{|c|c|c|}
\hline Population growth & & $0.5 \%$ \\
\hline Real return on bonds & & $2.0 \%$ \\
\hline Real return on equity & & $4.0 \%$ \\
\hline Rate of time preference & & $1.0 \%$ \\
\hline \multicolumn{3}{|l|}{ Elasticities of substitution } \\
\hline Intertemporal & & 0.5 \\
\hline Intratemporal (consumption-leisure) & & 1.0 \\
\hline Bonds-equity & & 4.0 \\
\hline Implied (semi-)elasticities & Min & $\operatorname{Max}$ \\
\hline Labour supply to wage & 0.12 & 0.28 \\
\hline Savings to interest rate & 0.35 & 0.80 \\
\hline
\end{tabular}

\section{$2.3 \quad$ Firms}

Two types of firms are distinguished: domestic firms and multinationals. A domestic firm only operates in one country. In each country a representative multinational headquarter is located and each multinational is assumed to own a subsidiary in each foreign country. ${ }^{7}$ The decisions by each firm are derived from maximising its value.

Production in each firm uses three primary factors: labour, internationally mobile capital and location specific capital. Location specific capital is supplied perfectly inelastically

\footnotetext{
${ }^{7}$ The location decision of a subsidiary is thus not modelled. In the absence of entry costs, multinationals only decide on the size of its subsidiaries.
} 
and is internationally immobile. Since its return, being a rent, is part of the corporate tax base, including this type of capital motivates a lower bound on the corporate income tax rate. Fixed income is assumed to accrue to the residents of the home country. In this way a tax export channel is incorporated, as host countries impose the corporate income tax on this income flow. Labour is also assumed internationally immobile, implying that firms have to compete for labour on the local market.

In contrast, capital is perfectly mobile internationally. Although the gross rate of return is fixed at the world capital market, the user cost of capital depends on country specific corporate and personal taxation systems. Investments can be financed by issuing bonds or by retaining profits (issuing new shares is not allowed). The equity capital of a subsidiary (defined as FDI) is provided by its parent. The optimal financing mix depends on the difference between the cost of debt financing (after corporate taxation) and the required return on retained profits. The latter is determined by the marginal equity holder, which is assumed to live in the home country. As a consequence, the required return on the firms' equity is determined by the tax rate the domestic household has to pay on equity income. As debt financing is in general tax-favoured, extreme debt positions are avoided by specifying financial distress costs that increase in the debt ratio.

Production in a subsidiary needs in addition an intermediate input that is provided by its parent company. A headquarter can charge a transfer price for these inputs that deviates from the real cost. When tax bases are not consolidated, a multinational has an incentive to shift profits to low-tax countries by setting a low transfer price. Profit shifting remains bounded by specifying that a multinational has to incur extra costs when applying transfer pricing. Corporate taxation issues are further discussed in the next subsection.

The calibration of the firm sector is summarised in Table 3. The capital and labour parameters in the production functions are determined by country specific labour income shares (corrected for the self-employed). Country specific TFP-levels are calibrated from figures on GDP per worker. We follow Sørensen (2001) in specifying that domestic firms use location specific capital about twice as much as multinational headquarters (the precise figure is $0.7 / 0.3)$. The amount of location specific capital used by each subsidiary is calibrated from data on bilateral FDI-stocks.

\subsection{Corporate taxation}

We consider two basic principles for taxing corporate income: the source and the residence principle. Next, we explain how we have translated the reform proposals by the EC in terms of the model. In the last subsection, the specification and calibration of compliance costs are described. 
Table 3: Key parameters and (semi-)elasticities of production ${ }^{a}$

\begin{tabular}{|c|c|c|}
\hline Technological growth & & $1.5 \%$ \\
\hline Economic rate of depreciation & & $5.0 \%$ \\
\hline Income share of location specific capital & & $2.5 \%$ \\
\hline Income share intermediate inputs in subsidiaries & & $10.0 \%$ \\
\hline \multicolumn{3}{|l|}{ Elasticity of substitution } \\
\hline Labour-capital & & 0.7 \\
\hline Implied semi-elasticities & Min & $\operatorname{Max}$ \\
\hline Capital stock to statutory CIT & -0.46 & 0.09 \\
\hline Incoming FDI to statutory CIT & -1.91 & -0.48 \\
\hline Debt to statutory CIT & 0.23 & 0.38 \\
\hline Incoming transfer price to statutory CIT & 0.74 & 2.14 \\
\hline
\end{tabular}

${ }^{a}$ expressed in annual terms.

\subsubsection{Source or residence principle}

In the base case all EU-countries tax corporate income on a source basis. The tax base is defined as the value of output (including the value of intermediate inputs for a multinational headquarter), minus the wage sum, interest payments on debt and depreciation allowances (minus the value of intermediate inputs for a subsidiary). The tax rules in the EU-countries only differ in the value of the depreciation rate for tax purposes. The tax parameters in the EU are discussed below.

The US adopts the world-wide residence principle (alternatively known as the method of world-wide credit, see Sørensen (2001)). The US taxes the total corporate income of its multinationals if the tax bill according to the US-tax rules exceeds the sum of the taxes paid by the parent and all subsidiaries in the source countries.

\subsubsection{Calibration}

The key parameters of the CIT system are the statutory tax rate and the fiscal depreciation rate (i.e. the tax allowance rate). Both are shown in Table 4. The legal tax rates are taken from Devereux et al. (2002), except for the new member states (Finkenzeller and Spengel, 2004) and Denmark (Nexia International, 2005).

The starting point in the calibration of the tax base is the marginal effective tax rate (METR) as calculated by Devereux et al. (2002). We take the METR for the case where 
$25 \%$ of new investments are financed with debt and $75 \%$ with equity. This is lower than the actual debt-equity mix $(40 \%, 60 \%)$ in order to ensure reasonable (depreciation) allowances. The rate of tax allowances, which encompass all kinds of tax deductions, is calibrated such that this METR is reproduced, as it is the best measure of how corporate income taxes affect marginal investments. We restrict the tax allowance rate between 5\% and 15\%, where the lower bound is given by the economic rate of depreciation and the upper bound is imposed to avoid the undesirable 'taxation paradox': when one allows for generous tax allowances (large difference between fiscal and economic rate of depreciation), simulating a reduction in the corporate tax rate might result in an increase in the cost of capital and a reduction of the capital stock. ${ }^{8}$

\subsubsection{Consolidation and formula apportionment}

Consolidation of the tax base for a multinational simply amounts to summing the tax bases of all firms that are located in a country that participates in the new system. Under homestate taxation, the rules of the parent country are applied. In the alternative proposals European rules are applied, see Table 1.

This tax base is apportioned to the participating tax authorities according to a prescribed formula. Each country is assigned a share $\phi_{i j}$ of the tax base (where $i$ and $j$ represent the home and host country, respectively), which it may tax at its own tax rate $\tau_{\pi, j}$ (except with EUCIT). This share is calculated as a weighted average of three factors: employment, capital stock and production: ${ }^{9}$

$$
\phi_{i j}=f^{L} \frac{L_{i j}}{L_{i}}+f^{K} \frac{K_{i j}}{K_{i}}+f^{Y} \frac{Y_{i j}}{Y_{i}}
$$

The weights of the three factors, denoted by $f^{L, K, Y}$, sum to one. The variable $L_{i j}$ denotes employment by a subsidiary in source country $j$ of a multinational from home country $i$. Total employment by multinational $i$ is thus given by $L_{i}=\sum_{j} L_{i j}$. When the consolidated tax base is allocated according to the labour shares, jurisdiction $j$ thus receives a fraction $L_{i j} / L_{i}$. The same notation applies for the capital and production factor. One can easily check that the shares sum to one for each multinational $\left(\sum_{j} \phi_{i j}=1\right)$. Our

\footnotetext{
${ }^{8}$ See Sørensen (2002). Only in Greece the small tax base still implies the taxation paradox, where a tax increase raises investments.

${ }^{9}$ In practice, it is difficult to define capital and to a lesser extent employment and production. This issue is outside the scope of the current paper, but interested readers might consult Martens-Weiner (2006). A second remark concerns the choice of production instead of sales as a factor in the apportionment formula. In our model, we are unable to define the destination of sales, as only the net exports of each country are known. This prohibits the use of sales in the formula, and we include output instead.
} 
starting point in the next section is a broad formula with equal weights on employment, capital and production, i.e. $f^{L}=f^{K}=f^{Y}=1 / 3$. Alternative formulae are investigated in section 4 .

The tax rate relevant for decisions by multinationals can be written as a weighted average of the tax rates applied by the participating jurisdictions:

$$
\tau_{\pi, i}^{f a}=\sum_{j} \phi_{i j} \tau_{\pi, j}
$$

In the determination of optimal input demands, multinationals take into account that they can affect the $\phi$-shares to minimise the overall tax rate $\tau_{\pi}^{f a}$. In other words, they can still use tax planning strategies with formula apportionment. ${ }^{10}$

To simplify the analysis, we consider that the FA-system is mandatory for the multinationals. Allowing for the proposed free choice between separate accounting (SA) and formula apportionment would complicate the analysis considerably. ${ }^{11}$

\subsubsection{Compliance costs}

A motivation for tax base consolidation is to reduce tax compliance costs for multinationals. The European Commission (2004a) reports extensive evidence on perceived compliance costs (these include costs required for company taxation and VAT, together with costs voluntarily incurred to minimise taxes). Compliance costs are estimated at $1.9 \%$ and $30.9 \%$ of taxes paid by large firms and SMEs, respectively. ${ }^{12}$ Costs are larger for firms with subsidiaries. The European Commission (2001) focuses on costs related to transfer pricing. Estimates of annual compliance costs range from 1 to 2 million euro for the group of medium-sized enterprises and 4 to 5.5 million euro for large multinational enterprises. Compliance costs of 7.5 million euro amount to $3 \%$ of CIT revenues. Devereux (2004) concludes from this EC-report that compliance costs likely range between $2.7 \%$ and $4 \%$ of CIT revenues.

As evidence suggests that compliance costs decrease relatively with the size of the firms, these costs could be modelled as a fixed cost. The disadvantage of this specification

\footnotetext{
${ }^{10}$ Tax planning is captured by an extra term in the first order conditions of optimal inputs. This term can be interpreted as an excise tax (or subsidy) on the factor that is included in the formula (Edmiston, 2002).

${ }^{11}$ The analysis would be easy if the discrete choice between the SA and FA system could be determined before solving the model. However, in this case choosing the tax system with the lowest tax obligations obviously requires the full general equilibrium solution.

${ }^{12}$ Small- and medium-sized enterprises are defined as companies with less than 250 employees.
} 
is that a reduction of compliance costs will not directly affect any of the firm's decisions. This simulation will only result in a direct, positive effect on the output volume when compliance costs are modelled as a variable cost. We therefore prefer to model these costs by introducing a new type of 'unproductive' worker, which are needed to keep the tax administration. This overhead labour is specified as a fixed fraction of the productive workers, increasing the wage cost by this fraction.

Since firm specific, nor country specific figures are available, the fraction of overhead labour is kept the same for all firms. This fraction is calibrated at $0.43 \%$, such that the simulated compliance costs amount to $10 \%$ of the CIT-revenues in the EU. When simulating a switch to the FA-system, compliance costs are abolished for all subsidiaries.

\subsection{Rest of the government}

Besides taxes on corporate income, tax revenues consist of residence-based taxes on labour income, dividends, capital gains, interest income and consumption. The expenditure side contains government consumption, interest payments on public debt and lump sum transfers. Government consumption as well as public debt are constant fractions of GDP.

Government behaviour is exogenously specified. When corporate tax revenues change after a reform, a specified tax rate has to be adjusted to close the government budget. In all simulations, the labour tax rate is chosen for this purpose. Simulations with a consumption-tax closure rule do not affect the main findings of the paper.

\subsection{General equilibrium}

Equilibrium must hold on each market:

- The labour market: the country specific wage adjusts to ensure that domestic supply meets domestic demand.

- The goods market: the surplus of production over domestic demand leads to net exports; the rest of the world is willing to absorb any volume of net exports at the fixed world price. The goods price acts as numeraire.

- The bonds market: all types of bonds (domestic or foreign, issued by firms or government) are perfect substitutes with a fixed return; the net supply of bonds by the rest of world is assumed to be perfectly elastic. The equity market is modelled similarly.

- The current account equals the change in the net foreign asset position (on the balance of payments) if all previous markets are in equilibrium (due to Walras law). 


\subsection{Main features of the base case}

Table 4 focuses on features of the base case (with SA), that are needed to understand differences in simulation outcomes over the countries.

1. The capital/labour ratio (relative to EU-average) identifies the labour intensive and the capital intensive countries. For the interpretation of the outcomes, we consider as labour intensive countries: POL, PRT, CZE, HUN, GBR, GRC, SWE, AUT and DNK. The capital intensive group consists of the remaining countries.

2. Variations in the wage rate are related to variations in the capital/labour ratio. Lowwage countries are attractive for multinationals that want to expand employment for tax planning reasons.

3. The inward FDI stock (fraction of GDP) indicates the size of foreign subsidiaries in each country, which is large in IRL, BLU and NLD. These open economies are subject to larger international spillovers.

4. The statutory corporate tax rate is known to vary considerably in the EU (from $13 \%$ in IRL to $40 \%$ in DEU in 2002). In the next sections the following countries are classified as low-tax countries: IRL, HUN, POL, SWE, CZE, FIN, DNK and GBR.

5. The effective tax rate also depends on the tax allowance rate. The following countries are characterised by a narrow tax base: GRC, ITA, PRT, SWE, ESP, AUT and FRA.

6. In the simulations the labour tax rate is adjusted to close the government budget. In cases in which tax revenues fall after a corporate tax reform, welfare losses will be larger for countries with a high initial labour tax rate (like SWE).

7. The importance of multinationals is also reflected in the fraction of corporate income taxes paid by domestic firms. Notice that in first instance the consolidation reforms only affect the multinationals. More than half of the CIT revenues originates from multinationals in BLU, IRL and NLD.

\section{Common consolidated base taxation}

In a recent communication, the European Commission (2006) emphasises the need for consolidation and proposes to proceed along the lines of the Common Consolidated Base 
Table 4: Characterisation of the base case, 2002, countries are ranked at increasing tax

\begin{tabular}{lrrrrrrrrr} 
rate & IRL & HUN & POL & SWE & CZE & FIN & DNK & GBR & PRT \\
\hline Capital/Labour (EU=1) & 1.58 & 0.63 & 0.40 & 0.76 & 0.57 & 1.05 & 0.90 & 0.70 & 0.42 \\
Wage (EU=1) & 1.12 & 0.50 & 0.41 & 0.95 & 0.43 & 0.89 & 0.98 & 1.05 & 0.67 \\
FDI_in (fraction of GDP) & 0.93 & 0.14 & 0.09 & 0.36 & 0.12 & 0.16 & 0.36 & 0.28 & 0.13 \\
FDI_out (fraction of GDP) & 0.22 & 0.01 & 0.00 & 0.37 & 0.00 & 0.31 & 0.22 & 0.29 & 0.06 \\
& & & & & & & & & \\
CIT rate & 0.13 & 0.18 & 0.19 & 0.28 & 0.28 & 0.29 & 0.30 & 0.30 & 0.33 \\
Tax allowance rate & 0.05 & 0.05 & 0.05 & 0.08 & 0.07 & 0.06 & 0.07 & 0.06 & 0.08 \\
Labour tax rate & 0.17 & 0.33 & 0.25 & 0.47 & 0.35 & 0.38 & 0.34 & 0.22 & 0.24 \\
CIT domestic firms (\%CIT) & 0.36 & 0.65 & 0.66 & 0.50 & 0.66 & 0.63 & 0.53 & 0.52 & 0.62 \\
& & & & & & & & & \\
& BLU & AUT & NLD & GRC & ESP & FRA & ITA & USA & DEU \\
\hline Capital/Labour (EU=1) & 0.95 & 0.88 & 1.02 & 0.71 & 0.94 & 1.29 & 1.16 & 1.12 & 1.03 \\
Wage (EU=1) & 1.21 & 1.02 & 1.16 & 0.69 & 0.78 & 1.20 & 0.97 & 1.10 & 0.95 \\
FDI_in (fraction of GDP) & 0.73 & 0.15 & 0.50 & 0.04 & 0.11 & 0.13 & 0.06 & 0.08 & 0.12 \\
FDI_out (fraction of GDP) & 0.66 & 0.09 & 0.84 & 0.01 & 0.03 & 0.23 & 0.06 & 0.06 & 0.20 \\
& & & & & & & & & \\
CIT rate & 0.34 & 0.34 & 0.35 & 0.35 & 0.35 & 0.35 & 0.38 & 0.39 & 0.40 \\
Tax allowance rate & 0.06 & 0.08 & 0.06 & 0.15 & 0.08 & 0.08 & 0.12 & 0.08 & 0.05 \\
Labour tax rate & 0.38 & 0.39 & 0.31 & 0.26 & 0.28 & 0.38 & 0.35 & 0.22 & 0.34 \\
CIT domestic firms (\%CIT) & 0.30 & 0.63 & 0.47 & 0.68 & 0.66 & 0.65 & 0.68 & 0.67 & 0.66 \\
\hline
\end{tabular}

Taxation (CCBT). ${ }^{13}$ This section sheds light on the economic and welfare implications of this proposal with the use of CORTAX. In modelling CCBT, we have to make three choices, which are yet unspecified in the proposals. First, we have to specify the common tax base. As explained in section 2, we capture the broadness of the tax base by the rate of tax allowances. We assume that this rate is harmonised at the (population) weighted average of the existing allowances (7.2\%). Compared with the existing tax systems, this choice implies a broadening of the tax base in 7 countries (France, Austria, Spain, Sweden, Portugal, Italy and Greece), whereas the tax base is narrowed in the other ten countries (see Table 4). Note that the tax base is harmonised for multinational enterprises (MNEs) only. Domestic firms still have to apply to the home tax rules. Second, we assume that

\footnotetext{
${ }^{13}$ The CCBT has been relabeled in (European Commission, 2006, p.3) to the 'Common Consolidated Corporate Tax Base'.
} 
the apportionment formula is defined on employment, capital and production, each with equal weight. ${ }^{14}$ Third, budget imbalances are compensated with a change in the labour tax rate.

\subsection{Firms}

Consolidation implies that the subsidiaries of a European multinational are treated as a single entity for tax purposes. ${ }^{15}$ The main arguments in favour of consolidation, as listed in section 1, are taken into account in our model. First, we assume that multinationals save on compliance costs, as they have to file only one (consolidated) corporate income tax return, where all affiliates are included. Second, consolidation makes profit shifting for tax purposes obsolete, as all profits are added up in a single tax base. In our model, this implies that transfer pricing becomes redundant. ${ }^{16}$

Figure 1: Average tax rate of MNEs, in deviation of the statutory rate in the home country $^{a}$

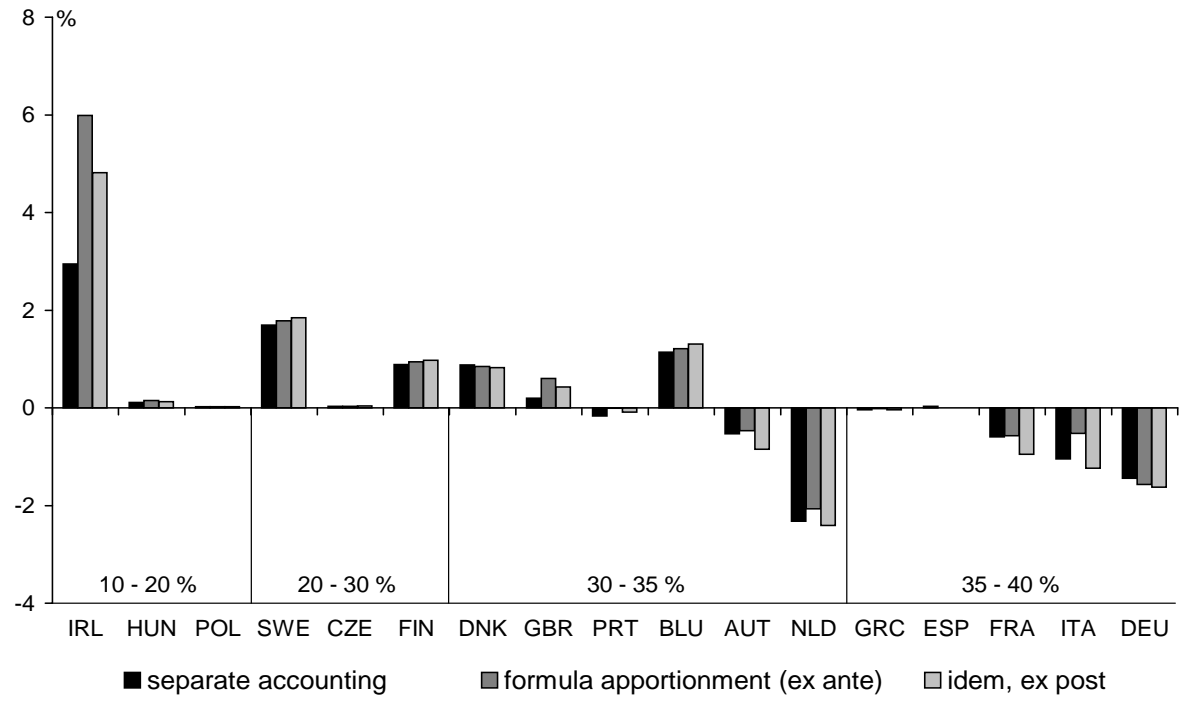

${ }^{a}$ Average tax rate of multinationals under separate accounting, formula apportionment - both before and after firms' responses. The initial tax rates are indicated on the $\mathrm{x}$-axis.

\footnotetext{
${ }^{14}$ In terms of equation (1) we assume that $f^{L}=f^{K}=f^{Y}=1 / 3$.

${ }^{15}$ Separate accounting still applies, however, for American firms and for the European subsidiaries in the United States.

${ }^{16}$ In addition, cross-border loss offset automatically occurs with tax base consolidation, see Nicodme (2006). This aspect is, however, hardly relevant in our model, given its steady state nature, where both parent firms and their subsidiaries generally generate positive profits.
} 
MNEs are confronted with changes in their tax base and in their average tax rate. The latter is calculated as a weighted average of the statutory rates of the countries in which the MNEs operate, see equation (2). Under separate accounting, the statutory rates are weighted with the share of each subsidiary in the total tax base of the MNE. For a firm in a low-tax country, like Ireland, this implies that the average tax rate is higher (3 percentage points) than the Irish statutory rate, see Figure 1. Key feature of separate accounting is that MNEs are able to affect their tax payments by shifting paper profits to low-tax countries. This reduces the average tax rate, in particular for firms with large production shares in the low-tax countries (which is usually the headquarter).

When formula apportionment is introduced, MNEs have to pay taxes proportional to the factors in the formula (labour, capital and production). However, these factors are less biased than the tax base towards the low-tax countries - at least in the initial situation (as shown in the ex-ante bars in Figure 1). As a result, the introduction of formula apportionment raises the ex-ante average tax rate in nearly all member states, most notably in Ireland.

Multinational enterprises may respond to formula apportionment by restructuring their production. Reallocation of labour across the border is very difficult as labour is hardly mobile internationally (immobile in our model). For example, the only way a German multinational can hire extra workers for its Polish subsidiary is by attracting employment from other Polish firms or from new labour supply. Therefore, the introduction of formula apportionment with a heavy weight on labour induces a reallocation of labour between firms within a country. Reallocation of capital can occur both within countries and across the border. However, the possibilities for firms to expand capital are limited by the production structure: firms need both capital and labour (with substitution elasticity of 0.7 ) in the production process. Firms respond to the change in the ex-ante tax rate by reallocating employment, investment and production, the three factors in the apportionment formula. As the three factors are equally weighted and moreover closely linked in the production process, we present the reallocation in terms of employment changes only.

The reallocation of employment given in Figure 2 is explained by three effects. The direct tax burden effect implies that MNEs want to reduce employment and investment in subsidiaries where the average ex-ante tax rate increases, which are the countries with low statutory rates, cf Figure 1. This implies a reduction of employment and capital by MNEs - both parents and subsidiaries - in low-tax countries (like Ireland, Hungary and Poland) and an increase of both production factors in high-tax countries like Germany and Italy.

The tax planning effect implies that firms want to benefit from the opportunity to reduce the tax burden by shifting activities to low-tax countries. Increasing the share of 
Figure 2: Reallocation of employment (\% labour force)

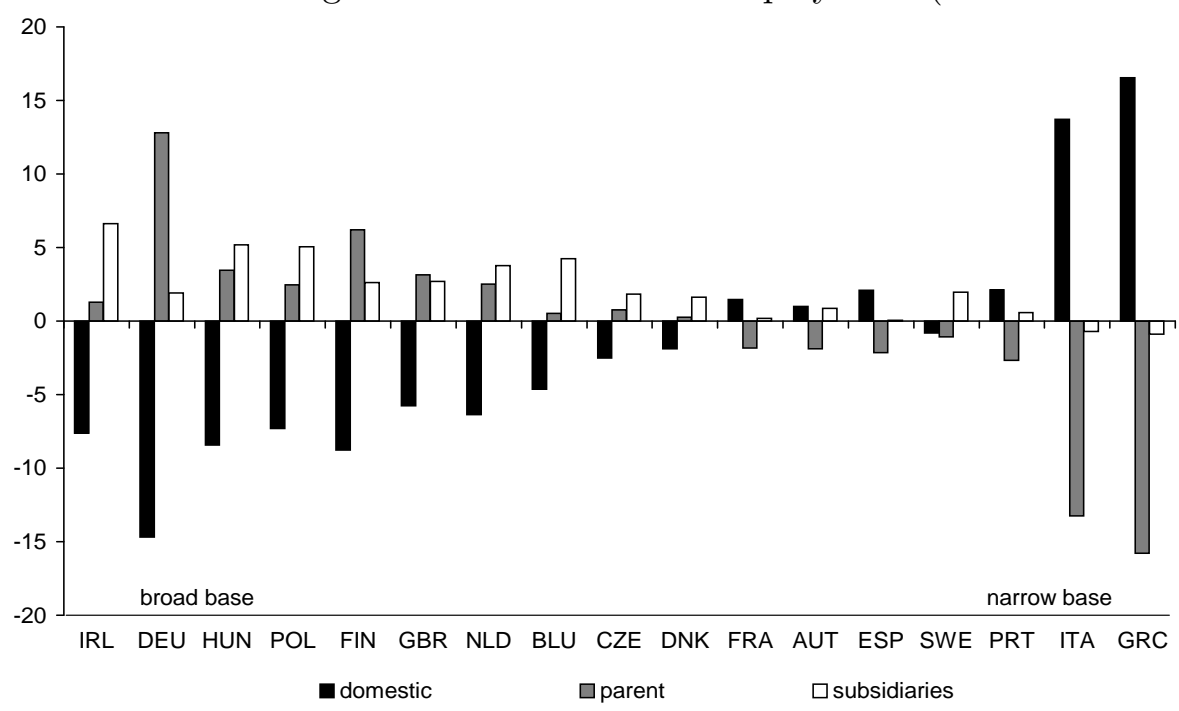

the factors in a low-tax country implies that a large share of the consolidated tax base is apportioned to these low-tax countries. In particular subsidiaries in low-tax countries (like Ireland, Hungary and Poland) expand at the expense of domestic firms and MNEheadquarters.

The base harmonisation effect arises from firms that want to avoid the effect of tax base broadening by reducing production in countries with initial small tax bases. In addition, the uneven treatment of multinationals and domestic firms determines the distribution of employment (and thereby investment) within each member state. In countries with an initial broad base, to which the domestic firms still have to apply, employment will be shifted towards MNEs who benefit from the narrower European tax base. This effect is clearly visible in all countries with a broader-than-average tax base (all countries in Figure 2 from Ireland to Denmark). The opposite shift from MNEs towards domestic firms is visible in member states with narrow bases like Greece and Italy. ${ }^{17}$

Figure 1 shows that this reallocation by MNEs reduces the average tax rate (ex post) in most member states, in particular in Ireland and Italy.

\footnotetext{
${ }^{17}$ The latter effect depends on the assumption that all MNEs are subject to the common tax rules. If they are allowed to choose between consolidation or the current system of separate accounting, they might prefer the latter.
} 


\subsection{Government}

How does the change from separate accounting to consolidation affect the tax revenues of governments? Under separate accounting (with the source principle) governments intend to tax the profits generated in their own country. With consolidation and formula apportionment, governments tax the apportioned share of the total taxable profits of each MNE. The changes in CIT-revenues, which are shown in Figure 3, therefore reflect changes in the tax base, not in the tax rate.

Figure 3: Changes in CIT revenues are exaggerated by firms' responses ${ }^{a}$

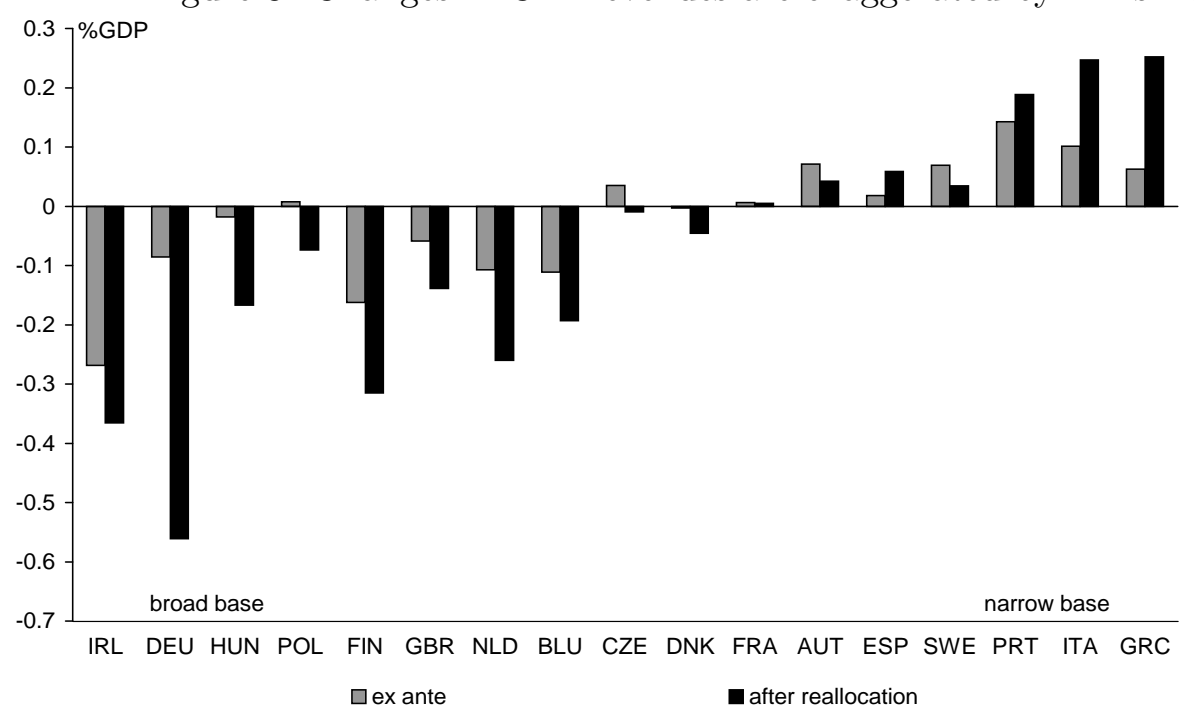

${ }^{a}$ Change in the revenues from the corporate income tax in percentage of GDP by changing from SA to FA, before and after reallocation. Countries are ranked according to their tax base.

Figure 3 decomposes the change in CIT-revenues in two parts. The ex-ante part shows the impact of consolidation as if firms do not respond. The dominant effect is the base harmonisation effect. Countries with an initial narrow base, in which the tax base is broadened to the EU average, will gain revenues, and vice versa. More complex is the impact of consolidation on the ex-post tax revenues. Under separate accounting a government taxes all firms located in the home country. In the new system a government may tax part (the apportioned part) of the consolidated base of all MNEs, next to total corporate income of domestic firms. The net impact of this second effect is ambiguous.

As we have discussed in the previous subsection, strong reallocation occurs in countries with extreme tax bases. For example, Italy and Greece are confronted with a strong outflow of MNEs, which implies a reallocation of labour and capital to domestic firms. This raises the CIT-revenues in both countries as the domestic firms are fully taxed at 
home, whereas MNEs can be taxed only partly. At the other extreme, countries in which the tax base is narrowed become more attractive for MNEs, at the expense of domestic firms. The higher corporate income in these countries is, however, only partly taxed by the domestic government.

The corporate income tax is, however, not the only source of revenues of the government - taxes on labour income and consumption are quantitatively more important. Reallocation has also important implications for the revenues of these taxes. In particular, labour income and consumption shrink in member states where wages decline as a result of a diminishing demand for labour. The reductions in revenues from labour and consumption taxes tend to counterbalance the improvement in CIT revenues, and vice versa. We assume that governments balance their budget by changing the tax rate on labour income. Table 5 shows that the labour tax rate has to be increased in countries with high CIT rates, where the opposite holds for low-tax countries. On average, a slight increase in the labour tax rate of 0.11 percentage points is needed to compensate the loss in total tax revenues.

\subsection{Economy and welfare}

Growth and jobs are central aims of European as well as national policies. The (European Commission, 2006, p.3) expresses the expectation that "(e)liminating tax obstacles such as high compliance costs for cross-border operations and transfer pricing and the lack of cross-border loss compensation in the internal market can contribute to these goals." How successful is, according to our model, the consolidation of the corporate tax base in reaching both goals in the long run?

Table 5 shows that CCBT slightly boosts GDP, but does not improve employment on average in the EU. The main stimulus for GDP and employment is the consolidation of the tax base at the common European rate. However, this efficiency gain is limited in this scenario as only the tax base for multinationals is harmonised (section 6.2 relaxes this assumption). The change in tax planning strategies is about neutral for GDP. On the one hand transfer pricing is eliminated, which reduces growth. The reason is that transfer pricing alleviates the tax burden for MNEs, and is therefore good for growth. On the other hand, new tax planning strategies will be applied by MNEs to alleviate the tax burden in the new system with formula apportionment. With the current formula, with equal weights on employment, capital and production, both effects cancel out in terms of GDP. The reason why employment does not increase is that the loss of tax revenues has to be compensated with an increase in the labour tax rate, which reduces the supply of labour. 
At this point it should not come as a surprise that consolidation, of the CCBT-type, hardly improves welfare in the EU (0.02\% of GDP). ${ }^{18}$ Tax planning remains important, tax revenues decline, GDP hardly grows and the impact on employment is neutral. Efficiency gains from curbing compliance costs and eliminating transfer pricing do not seem sufficient. ${ }^{19}$ The decomposition in Figure 4 helps to get a better grip on the welfare effects of consolidation. Three steps are distinguished:

1. the reduction of compliance costs;

2. harmonisation of the tax base for multinational enterprises at the EU-average;

3. consolidation of the tax base and the introduction of formula apportionment.

Figure 4: Decomposition of welfare (\%GDP) as function of the tax rate (left panel) and the tax base (right panel) ${ }^{a}$
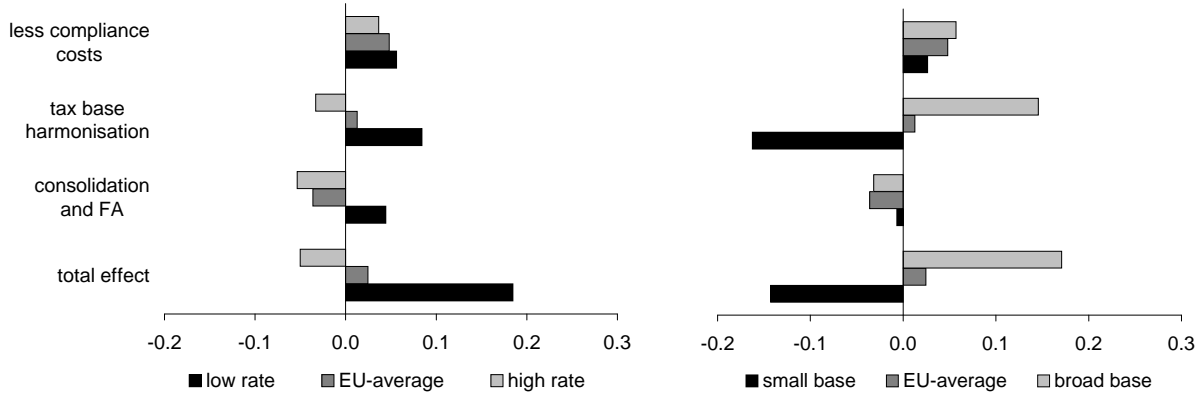

${ }^{a}$ The decomposition is given for CCBT with equal weight on employment, capital and production. The three steps are defined in the main text. The classification of the countries is given in section 2.7.

Figure 4 shows for each step how the welfare change depends on the statutory tax rate and the depreciation allowances of each member state. The reduction of compliance costs improves welfare for all member states, in particular for the outward oriented economies. The second step of tax base harmonisation clearly depends on the initial broadness of the tax base: welfare declines in member states with narrow bases where MNEs cut down production in response to the higher CIT burden. The welfare effects of consolidation with the introduction of formula apportionment (the third step) depend on the statutory tax rates of member states. The key channel in this third step is tax planning: MNEs have to give up transfer pricing, but may now utilise the apportionment formula to curb

\footnotetext{
${ }^{18}$ Welfare is given by the negative of the compensating variation, expressed as a $\%$ of GDP.

${ }^{19}$ Compliance costs are only abolished for the subsidiaries, not for the headquarters.
} 
tax payments. Simulations reveal that low-tax countries benefit from the switch in taxplanning strategies, unlike high-tax countries and unlike the EU on average. Why do low-tax countries benefit? It is not because their governments get higher CIT-revenues, on the contrary: favourable profit shifting is eliminated. The new tax planning opportunity implies, however, that MNEs expand in low-tax countries, which drives up wages, generates labour and consumption tax revenues and thus improves welfare. On average, this tax planning with real activities is more distortive than with transfer pricing, such that welfare in the EU declines in the third step. In sum, a tiny welfare gain of $0.02 \%$ GDP remains.

Table 5: Economic and welfare effects of Common Consolidated Base Taxation ${ }^{a}$

\begin{tabular}{lrrrrrrr}
\hline Country & $\mathrm{CIT}$ & $\tau_{l}$ & $\mathrm{w}$ & $\mathrm{L}$ & $\mathrm{K}$ & $\mathrm{GDP}$ & $\mathrm{CV}^{+}$ \\
\hline Ireland & -0.37 & 0.20 & 0.79 & 0.28 & 0.52 & -0.55 & 0.06 \\
Hungary & -0.17 & -0.14 & 0.53 & 0.23 & 1.04 & 0.17 & 0.22 \\
Poland & -0.07 & -0.18 & 0.42 & 0.19 & 0.86 & 0.13 & 0.23 \\
Sweden & 0.03 & -0.21 & 0.05 & 0.08 & -0.14 & -0.06 & 0.21 \\
Czech Republic & -0.01 & -0.13 & 0.16 & 0.08 & 0.33 & 0.05 & 0.11 \\
Finland & -0.31 & 0.21 & 0.57 & 0.05 & 1.17 & 0.41 & 0.11 \\
Denmark & -0.05 & -0.02 & 0.12 & 0.00 & 0.16 & 0.03 & 0.11 \\
United Kingdom & -0.14 & 0.01 & 0.36 & 0.06 & 1.04 & 0.16 & 0.18 \\
Portugal & 0.19 & -0.29 & -0.11 & 0.04 & -0.40 & -0.06 & 0.16 \\
Belgium \& Luxembourg & -0.19 & -0.09 & 0.51 & 0.11 & 1.19 & 0.54 & 0.37 \\
Austria & 0.04 & -0.03 & -0.05 & -0.02 & -0.17 & -0.09 & 0.02 \\
Netherlands & -0.26 & 0.23 & 0.51 & -0.09 & 1.45 & 0.36 & 0.21 \\
Greece & 0.25 & 0.03 & -0.77 & -0.14 & -1.51 & -0.72 & -0.40 \\
Spain & 0.06 & -0.04 & -0.12 & -0.02 & -0.26 & -0.09 & -0.02 \\
France & 0.01 & 0.19 & -0.08 & -0.17 & -0.29 & -0.18 & -0.11 \\
Italy & 0.25 & 0.10 & -0.68 & -0.23 & -1.34 & -0.70 & -0.33 \\
Germany & -0.56 & 0.48 & 0.95 & 0.03 & 2.62 & 0.82 & 0.12 \\
& & & & & & & \\
EU & -0.07 & 0.11 & 0.18 & -0.01 & 0.51 & 0.08 & 0.02 \\
USA & 0.00 & 0.00 & 0.00 & 0.01 & 0.01 & 0.00 & 0.00 \\
Formula apportionment is assumed to depend & on employment, capital and output with equal weights. \\
CIT: change in revenues from corporate income tax $\left(\%\right.$ GDP); $\tau_{l}$ : change in the labour-tax rate (\%-point); \\
w, L, K and GDP: relative change in wages, employment, capital and gross domestic production (\%); CV : \\
compensating variation (\% GDP) where a positive sign indicates a welfare gain. & \\
& & & & & & &
\end{tabular}




\section{The choice of the apportionment formula matters}

The European Commission (2006) acknowledges that consolidation involves 'possible mechanisms such as formula apportionment', but is still silent on which formula should be adopted. In the previous section, we have assumed the formula with equal weights on employment, capital and production. The current section explores the welfare effects of four alternative formulae with CCBT, see equation (1): ${ }^{20}$

- equal shares: equal weight on employment, capital and production;

$\phi_{j}=\frac{1}{3}\left(\frac{L_{j}}{L}\right)+\frac{1}{3}\left(\frac{K_{j}}{K}\right)+\frac{1}{3}\left(\frac{Y_{j}}{Y}\right)$

- employment: unit weight on employment; $\phi_{j}=L_{j} / L$

- capital: unit weight on capital; $\phi_{j}=K_{j} / K$

- production: unit weight on production; $\phi_{j}=Y_{j} / Y$

The welfare effects of the alternative formulae are presented in Table 6 . The distribution over the countries depends strongly on the design of the apportionment formula, whereas it only slightly matters for the EU on average. The large variety of welfare effects both between countries and across different formulae is explained by analysing the last step of the decomposition, discussed in Section 3. Notice that all formulae share the first step (lower compliance costs) and second step (base harmonisation effect).

The third step, where separate accounting is replaced by consolidation cum formula apportionment, includes three elements. First, profit shifting via transfer pricing is abolished. Second, a new means of tax planning is introduced, as firms may reduce the average tax rate by shifting economic activity towards the low-tax countries. Third, the average corporate tax rate of multinationals changes which induces a change in investments. Each element depends on the tax-rate differentials. Moreover, the tax planning and direct tax burden effect depend on the intensity of each factor in each country: e.g. labour intensive countries get a large share of the consolidated base if apportionment is based on employment shares. Below, we illustrate that the welfare effects depend on the labour intensity and tax differentials of member states.

\footnotetext{
${ }^{20}$ We assume that all member states adopt the same formula with same weights. Competition between member states in the choice of formula or the relative weights of each factor is outside the scope of the current paper. Evidence for the US is reported in Goolsbee and Maydew (2000), Edmiston (2002) and Omer and Shelley (2004), showing that the ability of each jurisdiction to change and strategically determine its factor weights has, in general, negative welfare implications. Competition in tax rates is discussed in section 5 .
} 
Table 6: Welfare effects of alternative apportionment formulae ${ }^{a}$

\begin{tabular}{llrrrr}
\hline & Key features & Equal shares & Employment & Capital & Production \\
\hline Ireland & broad base, capital intensive & 0.06 & -0.36 & 0.77 & -0.01 \\
Hungary & broad base, labour intensive & 0.22 & 0.53 & 0.16 & 0.08 \\
Poland & broad base, labour intensive & 0.23 & 0.87 & 0.08 & 0.08 \\
Sweden & & 0.21 & 0.38 & -0.03 & 0.26 \\
Czech Rep. & labour intensive & 0.11 & 0.32 & 0.06 & -0.01 \\
Finland & broad base, capital intensive & 0.11 & -0.03 & 0.36 & -0.03 \\
Denmark & & 0.11 & 0.04 & 0.18 & 0.09 \\
UK & broad base & 0.18 & 0.28 & 0.02 & 0.23 \\
Portugal & labour intensive & 0.16 & 0.40 & -0.07 & 0.14 \\
Belgium \& Lux. & & 0.37 & 0.12 & 0.17 & 0.74 \\
Austria & & 0.02 & -0.05 & -0.02 & 0.10 \\
Netherlands & broad base & 0.21 & -0.03 & 0.31 & 0.32 \\
Greece & narrow base & -0.40 & -0.38 & -0.41 & -0.41 \\
Spain & & -0.02 & -0.03 & 0.00 & -0.05 \\
France & capital intensive & -0.11 & -0.34 & 0.03 & -0.08 \\
Italy & narrow base, capital intensive & -0.33 & -0.37 & -0.30 & -0.35 \\
Germany & broad base & 0.12 & 0.00 & 0.19 & 0.08 \\
European Union & & & & & \\
\hline
\end{tabular}

${ }^{a}$ Measured by $C V^{+} / G D P$. A positive sign indicates a welfare gain. The countries are ranked at increasing tax rates. The classification of the countries is given in section 2.7.

Figure 5 confirms that the labour intensity of member states determines the welfare effect of formula apportionment, in particular if apportionment is based on employment shares. Member states with labour-intensive production benefit from apportionment on employment shares. First, corporate tax revenues increase in labour-intensive countries, see Devereux and Loretz (2007). These additional tax revenues are used to cut the labour tax rate, which in turn improves welfare. Second, tax planning implies that multinationals expand employment in low-tax countries, in particular in countries where labour is abundant and therefore cheap. The wage differentials therefore exaggerate the distortion from apportionment according to the employment factor. This second effect is less important if apportionment is based on capital shares, because the cross-country variation in the return to capital is much smaller than the variation in wages. Therefore, the variation in welfare effects is less pronounced with apportionment according to the capital factor, which also explains the smaller welfare loss in the EU.

The variation in welfare effects hardly depends on the variation in capital intensity with apportionment according to production. Instead, it is determined by the variation 
Figure 5: The change in welfare in the consolidation step in labour- and capital intensive countries $(\% \mathrm{GDP})^{a}$

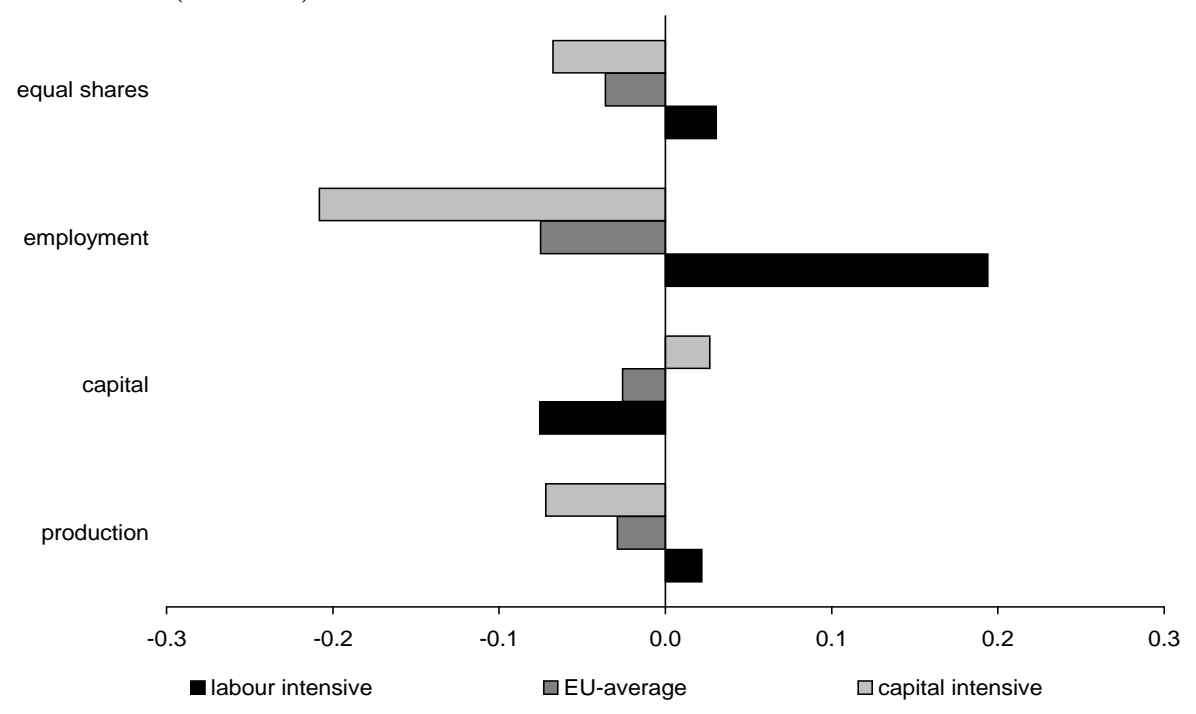

${ }^{a}$ The list of labour-intensive versus capital-intensive countries is given in section 2.7.

in total factor productivity (TFP). Countries with a high TFP (like the United Kingdom, the Netherlands and Belgium \& Luxembourg; Table 6) benefit from a larger share of the consolidated tax base.

Figure 6: The change in welfare in the consolidation step in low-tax and high-tax countries $(\% \mathrm{GDP})^{a}$

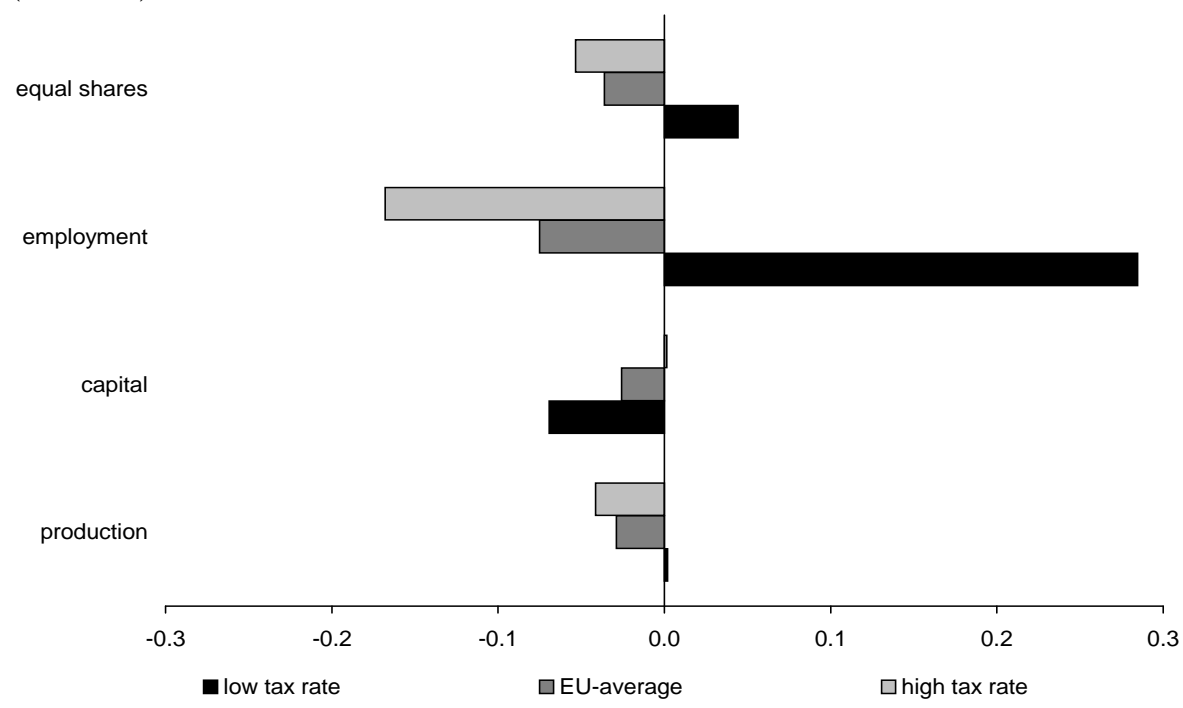

${ }^{a}$ The list of low and high-tax countries is given in section 2.7. 
Figure 6 shows that the apportionment formula crucially determines which countries benefit from consolidation: low-tax countries benefit from apportionment according to employment factors, but not according to capital or production factors. Again the tax planning and tax burden effects explain this variation. Tax planning via transfer pricing is abolished, which impairs low-tax countries. Formula apportionment introduces new taxplanning opportunities for multinationals which expand production in low-tax countries. The latter effect is relatively strong with apportionment according to the employment factor, which is the main reason why low-tax countries benefit from the employment formula. Finally, the tax burden of low tax countries increases with all four apportionment formulae, because the return to capital is no longer subject to the corporate tax rate in the home country, but to the higher average tax rate in the EU (cf. Figure 1).

In sum, two key effects determine the economics of formula apportionment. First, the apportionment formula directly determines the share of consolidated profits allocated to each country. Countries benefit most from a formula putting a large weight on their abundant factor, e.g. labour intensive countries benefit from a high weight on labour. Second, multinationals may respond to formula apportionment by reallocating their activity to low-tax countries. This reallocation will occur with all kinds of formulae, but the intensity of reallocation may vary. Reallocation will be strongest if employment gets a large weight, in which case firms may exploit wage differentials in addition to tax-rate differentials.

\section{Competition in tax rates}

The effects of moving to consolidation with formula apportionment (FA) on tax competition are theoretically ambiguous (see e.g. Pethig and Wagener (2003), Sørensen (2004) and Kind et al. (2005)). Whether FA triggers more tax competition than separate accounting hinges on the comparison of the tax spillovers. Governments under the SA method have an incentive to underbid each other tax rates to attract paper profits, while with FA they keep tax rates low to attract multinational activities (Gordon and Wilson, 1986). Which of these spillovers dominate remains an empirical issue.

We explore whether consolidation intensifies tax competition by searching the unilateral change in the tax rate that maximizes welfare of the corresponding country, while keeping the rates of the other countries at the observed levels. ${ }^{21}$ Figure 7 first shows, next to the actual tax rate (in 2002), the optimal response under SA (left bar). ${ }^{22}$ The optimal

\footnotetext{
${ }^{21}$ The optimal tax rate is one point of the country's reaction curve. This point should not be interpreted as the uncoordinated Nash equilibrium of this asymmetric game.

${ }^{22}$ These results are discussed in more detail in (Bettendorf et al., 2006, section 4.3).
} 
tax rate under SA is found close to the actual rate for many countries. The right bar gives the optimal tax rate under CCBT. This rate is lower than the optimal rate under SA for each country, indicating that tax competition is more fierce with FA. Differences are large for countries with a large share of multinationals, like Ireland, Belgium and the Netherlands. Small deviations are found for relatively closed economies like UK, France and Germany.

The intensification of tax competition under FA also results with other factor weights. Simulations show that tax competition will be sharper the more elastically the apportionment formula reacts upon tax changes (which is in line with the theoretical result of Pethig and Wagener (2003)). In the last section we discussed that reallocation effects are larger when employment gets the full weight in the formula. The optimal tax rate is in this case on average $10 \%$ lower than the actual rate, while the average reduction equals $8 \%$ when the formula with a unit weight on capital is applied (compare with a reduction by $4 \%$ and $7 \%$ under SA and FA with equal weights, respectively). ${ }^{23}$

Figure 7: More tax competition with formula apportionment ${ }^{a}$

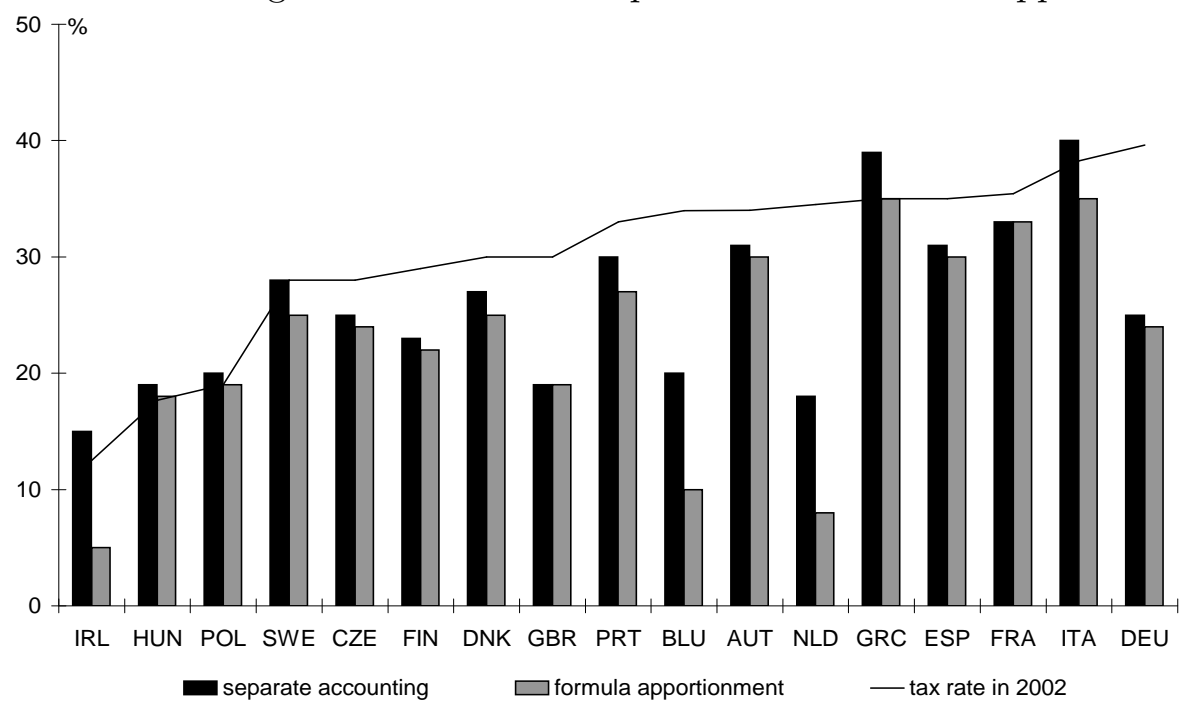

${ }^{a}$ The figure shows the optimal tax rates for each member state, assuming that other countries do not adjust their rates, in two scenarios: with separate accounting and with CCBT with formula apportionment $(1 / 3$ weight on labour, capital and production).

\footnotetext{
${ }^{23}$ The unweighted average reductions are given in \%-points.
} 


\section{Alternative consolidation approaches}

Various alternatives types of consolidation have been put forward by the European Commission in its 2002 Tax Communication. ${ }^{24}$ It is worthwhile to investigate these alternative proposals for a couple of reasons. First, although the common base consolidation is put forward in recent communications, like European Commission (2006), the alternatives have not been dismissed altogether and might receive renewed attention in the near future. Second, simulating the most far-reaching proposals, with consolidation of the tax base and harmonisation of the tax rate, offers insight in the potential gains from consolidation as it eliminates most tax distortions between member states.

This section discusses the consequences of Home State Taxation (HST), of compulsory consolidation for all firms and of the far-reaching proposal of the European Union Company Income Tax (EUCIT), where even tax rates are harmonised.

\subsection{Home State Taxation}

The consolidated tax base is calculated according to the rules of the home state. We assume that all European MNEs change to the new system, but domestic firms have to stick to the tax rules of their home country. Like in section 3, we assume that formula apportionment is defined with equal weights on employment, capital and production.

Home state taxation implies that the tax base of domestic firms and domestic MNEs are defined similarly, but MNEs from different home states are subject to different tax rules. In comparison with CCBT, an extra distortion is therefore created. Detailed outcomes show that the average rate of fiscal depreciation hardly changes for MNEs (in comparison with the current SA system), implying that reallocation is mainly driven by tax rate differentials. As a consequence, multinationals expand at the expense of domestic firms in low-tax countries. They have to bid up wages in order to attract employment from domestic firms. As a result, revenues from labour and consumption taxes increase. The opposite holds for high-tax countries, which in addition face a reduction in CIT-revenues due to unfavourable reallocation effects.

The effects of home state taxation are summarised in columns (4)-(6) of Table 7. The welfare gain in low-tax countries reflects the rise in net income of households, due to a higher wage rate and a reduction in the labour tax rate. ${ }^{25}$ However, the expansion of production by MNEs goes at the expense of domestic firms. For many low-tax member

\footnotetext{
${ }^{24}$ See section 1 and more recently in communications on Home State Taxation (European Commission, 2004c, 2005).

${ }^{25}$ Ireland is an exception since it suffers from less broad tax bases of its foreign subsidiaries.
} 
Table 7: Changes in employment $(\mathrm{L})$, production $(\mathrm{Y})$ and welfare $\left(\mathrm{CV}^{+}\right)$for alternative consolidation proposals ${ }^{a}$

\begin{tabular}{lrrrrrrrrrrrr}
\hline & \multicolumn{1}{c}{ CCBT } & \multicolumn{4}{c}{ HST } & \multicolumn{4}{c}{ CHCTB } & \multicolumn{3}{c}{ EUCIT } \\
& $L$ & $Y$ & $C V^{+}$ & $L$ & $Y$ & $C V^{+}$ & $L$ & $Y$ & $C V^{+}$ & $L$ & $Y$ & $C V^{+}$ \\
& $(1)$ & $(2)$ & $(3)$ & $(4)$ & $(5)$ & $(6)$ & $(7)$ & $(8)$ & $(9)$ & $(10)$ & $(11)$ & $(12)$ \\
\hline IRL & 0.28 & -0.55 & 0.06 & 0.25 & -0.79 & -0.09 & 0.29 & -0.19 & 0.22 & 0.41 & -2.41 & -0.14 \\
HUN & 0.23 & 0.17 & 0.22 & 0.21 & -0.10 & 0.16 & 0.27 & 0.67 & 0.46 & 0.72 & -0.22 & 0.47 \\
POL & 0.19 & 0.13 & 0.23 & 0.18 & -0.04 & 0.19 & 0.20 & 0.48 & 0.39 & 0.53 & -0.15 & 0.35 \\
SWE & 0.08 & -0.06 & 0.21 & -0.17 & -0.33 & 0.18 & 0.12 & -0.12 & 0.11 & 0.25 & -0.38 & 0.08 \\
CZE & 0.08 & 0.05 & 0.11 & 0.05 & -0.05 & 0.09 & 0.09 & 0.19 & 0.17 & 0.22 & -0.23 & 0.09 \\
FIN & 0.05 & 0.41 & 0.11 & 0.11 & 0.21 & -0.08 & 0.29 & 1.20 & 0.53 & 0.48 & 0.98 & 0.51 \\
DNK & 0.00 & 0.03 & 0.11 & -0.08 & -0.10 & 0.07 & 0.07 & 0.15 & 0.15 & 0.18 & -0.03 & 0.14 \\
GBR & 0.06 & 0.16 & 0.18 & 0.09 & 0.04 & 0.09 & 0.08 & 0.51 & 0.34 & 0.13 & 0.34 & 0.30 \\
PRT & 0.04 & -0.06 & 0.16 & 0.02 & -0.01 & 0.20 & 0.03 & -0.25 & 0.08 & 0.03 & -0.26 & 0.07 \\
BLU & 0.11 & 0.54 & 0.37 & 0.06 & 0.30 & 0.20 & 0.26 & 0.84 & 0.46 & 0.23 & 0.87 & 0.47 \\
AUT & -0.02 & -0.09 & 0.02 & -0.09 & -0.16 & 0.03 & -0.03 & -0.21 & -0.05 & -0.04 & -0.17 & -0.05 \\
NLD & -0.09 & 0.36 & 0.21 & 0.00 & 0.18 & 0.04 & 0.06 & 0.92 & 0.47 & 0.11 & 1.07 & 0.52 \\
GRC & -0.14 & -0.72 & -0.40 & -0.04 & -0.07 & 0.01 & -0.29 & -2.69 & -1.07 & -0.34 & -2.61 & -1.05 \\
ESP & -0.02 & -0.09 & -0.02 & -0.03 & -0.03 & 0.00 & -0.03 & -0.30 & -0.09 & -0.09 & -0.20 & -0.07 \\
FRA & -0.17 & -0.18 & -0.11 & -0.27 & -0.26 & -0.12 & -0.14 & -0.28 & -0.16 & -0.22 & -0.19 & -0.14 \\
ITA & -0.23 & -0.70 & -0.33 & -0.20 & -0.22 & 0.00 & -0.37 & -2.30 & -0.74 & -0.58 & -2.05 & -0.68 \\
DEU & 0.03 & 0.82 & 0.12 & 0.10 & 0.34 & -0.02 & 0.28 & 2.11 & 0.70 & 0.11 & 2.50 & 0.84 \\
EU & -0.01 & 0.08 & 0.02 & -0.01 & -0.01 & 0.02 & 0.03 & 0.17 & 0.12 & 0.02 & 0.21 & 0.15 \\
\hline
\end{tabular}

${ }^{a} L$ and $Y$ denote the relative change (\%) in respectively total employment and GDP, $C V^{+}$represents the compensating variation (\% GDP), where a positive sign indicates a welfare gain.

CCBT: common consolidated base taxation, see section 3; HST: home state taxation, see section 6.1; CHCTB: compulsory harmonised corporate tax base, see section 6.2; EUCIT: European Union company income tax, see section 6.3.

The countries are ranked at increasing tax rates. 
states, the net effect is a reduction in GDP and a smaller capital stock.

The EU on average hardly gains nor loses from home state taxation; welfare is lower than under CCBT. The consolidation gains are neutralised by the distortive effect of formula apportionment and the unlevel playing field for MNEs from different member states.

\subsection{Compulsory consolidation}

Neither CCBT nor HST will deliver the welfare gain which is expected from consolidation. In both cases, uneven treatment of firms (within or between countries) and formula apportionment in combination with the large tax-rate differentials are identified as the culprits. Both culprits will be removed in turn. We first make the common system compulsory which yields the compulsory harmonised corporate tax base (CHCTB). The next subsection adds the harmonisation of the tax rates.

We harmonise the base of the CIT at the EU average of $\delta_{t}^{E U}=7.2 \%$. Both domestic and multinational enterprises have to switch to this common tax base. As before, FA is applied with one-third shares on employment, capital and production.

Reallocation between firms within countries gets less distorted as the tax base is uniformly defined for all firms. This contrasts with the CCBT, where this reason for reallocation is important in member states with either very broad or very narrow tax bases, like Germany respectively Greece (see section 3). If all countries apply the same tax base for all firms, country specific tax rates remain the only reason for reallocation. Multinational enterprises will reduce their tax obligations by expanding the subsidiaries in low-tax countries.

How large are the efficiency gains if all countries harmonise their CIT base for both MNEs and domestic firms? Columns (7)-(9) of Table 7 show the welfare change for the EU and the member states. Welfare in the EU improves on average by $0.12 \%$ GDP if the common tax base applies to all firms. This shows that the design of consolidation is crucial: consolidation will only be beneficial if it does not introduce new distortions between firms.

Despite the average welfare gain, the distribution of gains and losses is very uneven. This is mainly due to the initial heterogeneity in the broadness of the tax base. In general, member states benefit from a narrowing of their base, but lose if the common base is broader than their existing base. A noticeable exception is Sweden, where the additional CIT-revenues from a broader base can be used for a reduction in the highly distortive tax on labour income. 


\subsection{European Union Company Income Tax}

The most far-reaching proposal for consolidation is the harmonisation of not only the tax base but also the tax rate. A proposal in this direction is the European Union Company Income Tax (EUCIT). ${ }^{26}$ We investigate this proposal to show the potential welfare gain of consolidation, i.e. if all tax distortions between countries are minimised. This gain is reached if the CIT base and rate are harmonised for both MNEs and domestic firms. We harmonise both the rate and the base of the tax on corporate income at the EU average of respectively $\tau_{p}^{E U}=33.3 \%$ and $\delta_{t}^{E U}=7.2 \%$. As before, the formula with equal weights is adopted.

Consolidation cum harmonisation eliminates all tax incentives for reallocation. A slight amount of reshuffling of capital and labour will occur, however, as the initial situation is non-neutral: subsidiaries in low-tax countries are relatively large in order to benefit optimally from profit shifting. This skewed initial situation will be neutralised with the EUCIT.

Figure 8: The change in welfare with alternative approaches (\%GDP) ${ }^{a}$

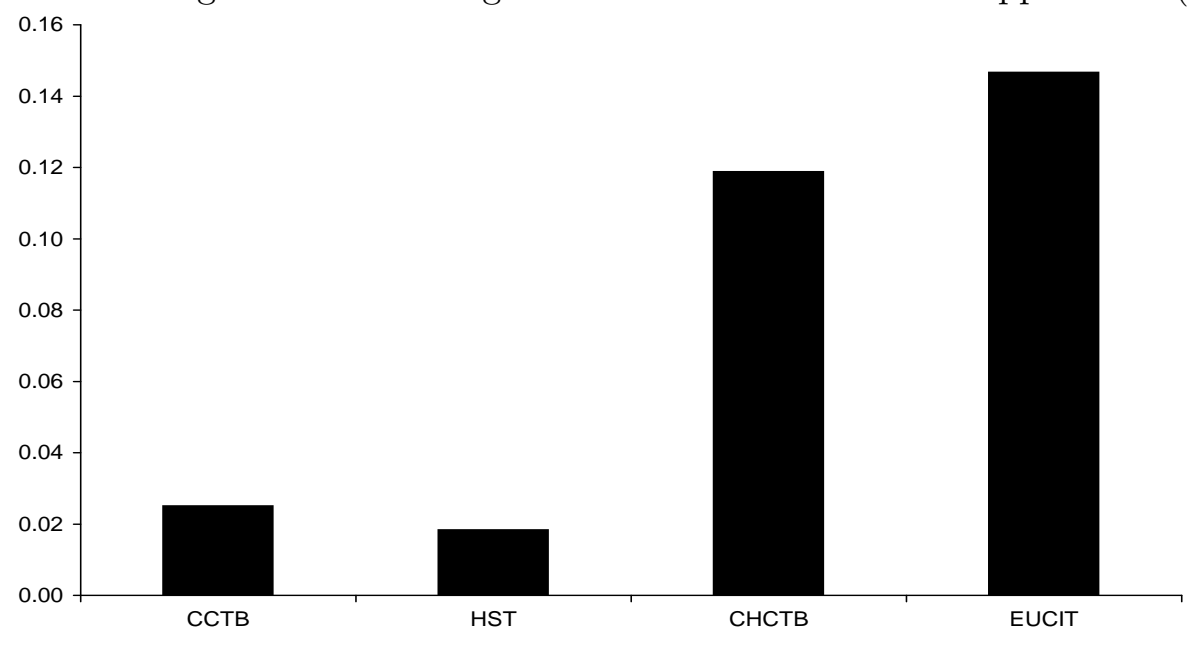

${ }^{a}$ The figure shows the change in welfare (as \%GDP) for alternative assumptions on the common base: for MNEs only (CCBT), compulsory for all firms (CHCTB) and if the tax rates are harmonised too (EUCIT), complemented with home state taxation (HST) where national rather than European rules apply.

\footnotetext{
${ }^{26}$ In this proposal, the CIT-revenues might become a direct finance source of the EU. As the EU is not included as a separate entity in the model, tax revenues are distributed to the member states. The correlation between the observed shares of the contribution of the considered member states (in 2002, see European Commission (2004b)) and the simulated shares in the CIT revenues equals 0.98. Therefore, under the assumption that the new EU-revenues will partially replace the existing contributions by the member states, our way of modelling these flows does not affect the outcomes.
} 
Due to the limited incentives for reallocation, harmonisation of the tax rate generates an additional welfare gain of about $0.03 \%$ GDP, as is shown in Figure 8 . The total welfare gain of $0.15 \%$ GDP is in line with similar simulations by Sørensen (2004) yielding a welfare gain of full harmonisation between 0.1 and $0.2 \%$ GDP. The figure illustrates the central finding of this section: the benefits from the common consolidated base can be fully obtained if the common base is compulsory for all firms and if in addition the tax rates are harmonised. ${ }^{27}$

\section{Conclusion}

The main benefits from replacing separate accounting by a consolidated corporate income tax base are the elimination of paper profit shifting, the introduction of automatic loss compensation for cross-border activities and the reduction of compliance costs. However, as consolidation introduces incentives for reallocation, the largest gains are only achieved when new distortions are minimised. Simulations in this paper highlight the key options of the consolidation reform in the EU.

First, the tax base should be defined the same for all firms, either domestic or multinational and irrespective of its origin. The participating countries should treat all firms equally by adopting a single, compulsory system. In this way, uneven competition between firms is reduced, such that most of the consolidation benefits are secured.

Second, the apportionment formula is another crucial choice of the consolidation system. The design of the formula should limit the scope for harmful tax planning by MNEs. Simulation outcomes show that welfare losses are the largest when employment gets a large weight in the formula, since the distorting effects of tax rate differentials are enforced by wage differentials in this case. Moreover, the strong reallocation effects also explain that tax competition is most fierce in this case. Both tax planning by multinationals and tax competition by governments can be overcome by complementing consolidation with harmonisation of the tax rates.

The welfare effects of consolidation will be unevenly distributed between member states, given the diversity in the current CIT-systems and induced by the heterogeneous effects of consolidation and formula apportionment. The EU as a whole will benefit the most from consolidation when the system is made compulsory and the tax rates are harmonised.

\footnotetext{
${ }^{27}$ This does not imply that harmonisation of the tax rate is the first best policy. It only shows that harmonisation is better for average welfare in the EU than the current situation with large tax differentials, but it does not exclude that alternative scenario's allowing for variation in tax rates might be even better.
} 


\section{References}

Bettendorf, L., Gorter, J., and van der Horst, A. (2006). Who benefits from tax competition in the European Union? CPB Document 125.

Bettendorf, L. and van der Horst, A. (2006). Documentation of CORTAX. CPB Memorandum 161. Available at www.cpb.nl.

Bettendorf, L. and van der Horst, A. (2007). Modelling the residence principle and formula apportionment in CORTAX. Mimeo CPB. available at www.cpb.nl/eng/org/homepages/avdh.

Cnossen, S. (2003). Some reflections on the Bolkestein Report. De Economist, 151(2):225237.

Devereux, M. (2004). Debating proposed reforms of the taxation of corporate income in the European Union. International Tax and Public Finance, 11:71-89.

Devereux, M., Griffith, R., and Klemm, A. (2002). Corporate income tax reforms and international tax competition. Economic Policy: A European Forum, 35:449-488.

Devereux, M. P. and Loretz, S. (2007). The effects of EU formula apportionment on corporate tax revenues. Working paper 07/06, Oxford University Centre for Business Taxation.

Edmiston, K. D. (2002). Strategic apportionment of the state corporate income tax. National Tax Journal, 40(2):239-261.

European Commission (2001). Towards an internal market without tax obstacles: A strategy for providing companies with a consolidated corporate tax base for their EUwide activities. Communication $\operatorname{COM}(2001) 582$.

European Commission (2002). Company taxation in the internal market. Communication $\operatorname{COM}(2001) 582$ Final.

European Commission (2004a). European Tax Survey. Taxation Papers 3.

European Commission (2004b). Financial Report 2004.

European Commission (2004c). Home state taxation for small and medium-sized enterprises. Commission Non-Paper to informal Ecofin Council, 10 and 11 September 2004. 
European Commission (2005). Tackling the corporation tax obstacles of small and medium-sized enterprises in the internal market; outline of a possible home state taxation pilot scheme. Communication $\operatorname{COM}(2005) 702$.

European Commission (2006). Implementing the Community Lisbon Programme: Progress to date and next steps towards a Common Consolidated Corporate Tax Base (CCCTB). Communication $\operatorname{COM}(2006) 157$ final.

Finkenzeller, M. and Spengel, C. (2004). Measuring the effective levels of company taxation in the new member states: A quantitative analysis. Working Paper 7/2004, European Commission.

Gérard, M. (2002). Neutralities and non-neutralities in international corporate taxation: An evaluation of possible and recent moves. Ifo-Studien, 48(4):533-554.

Gérard, M. (2006). Reforming the taxation of multijurisdictional enterprises in Europe: A tentative appraisal. Presented at the workshop on corporate tax competition and coordination in Europe, Directorate-General for Economic and Financial Affairs, Brussels.

Goolsbee, A. and Maydew, E. L. (2000). Coveting thy neighbor's manufacturing: The dilemma of state income apportionment. Journal of Public Economics, 75(1):125-143.

Gordon, R. and Wilson, J. D. (1986). An examination of multijurisdictional corporate income taxation under formula apportionment. Econometrica, 54(6):1357-1373.

Gupta, S. and Hofmann, M. A. (2003). The effect of state income tax apportionment and tax incentives on new capital expenditures. Journal of American Taxation Association, 25:1-25.

Hellerstein, W. and McLure, C. E. (2004). The European Commission's report on company income taxation: What the EU can learn from the experience of the US states. International Tax and Public Finance, 11(2):199-220.

Kind, H. J., Midelfart, K. H., and Schjelderup, G. (2005). Corporate tax systems, multinational enterprises, and economic integration. Journal of International Economics, 65:507-521.

Klassen, K. J. and Shackelford, D. A. (1998). State and provincial corporate tax planning: Income shifting and sales apportionment factor management. Journal of Accounting and Economics, 25:385-406. 
Martens-Weiner, J. (2006). Company Tax Reform in the European Union: Guidance from the United States and Canada on Implementing Formulary Apportionment in the EU. Springer, New York.

McLure, C. E. (1980). State corporate income tax: Lambs in wolves' clothing? In Aaron, H. and Boskin, M., editors, The Economics of Taxation. Brookings, Washington.

Mintz, J. and Smart, M. (2004). Income shifting, investment, and tax competition: Theory and evidence from provincial taxation in Canada. Journal of Public Economics, 88:11491168 .

Nexia International (2005). International Handbook of Corporate and Personal Taxes. Tottel UK.

Nicodme, G. (2006). Corporate tax competition and coordination in the European Union: What do we know? Where do we stand? Economic Papers 250, European Commission.

Nielsen, S. B., Raimondos-Møller, P., and Schjelderup, G. (2006). Company taxation and tax spillovers: Separate accounting versus formula apportionment. Copenhagen Business School, mimeo.

Omer, T. C. and Shelley, M. K. (2004). Competitive, political, and economic factors influencing state tax policy changes. Journal of the American Taxation Association, $26: 103-126$.

Pethig, R. and Wagener, A. (2003). Profit tax competition and formula apportionment. CESifo Working Paper 1010, Munich.

Riedel, N. and Runkel, M. (2007). Company tax reform with a water's edge. Journal of Public Economics, 91:1533-1554.

Sørensen, P. B. (2001). OECDTAX: a model of tax policy in the OECD economy. EPRU, University of Copenhagen.

Sørensen, P. B. (2002). The German business tax reform of 2000 - a general equilibrium analysis. German Economic Review, 3:347-378.

Sørensen, P. B. (2004). Company tax reform in the European Union. International Tax and Public Finance, 11:91-115.

Weiner, J. (2002). Would introducing formula apportionment in the european union be a dream come true or the eu's worst nightmare? Ifo-Studien, 48(4):519-532. 